\title{
Risiko gangguan makan dan kejadian anemia pada mahasiswa putri program studi S1 gizi STIKES mitra keluarga
}

Eating disorder risk and anemia among girls nutrition students in Mitra Keluarga school of healths sciences

Muh. Nur Hasan Syah ${ }^{1 *}$, Alfi Fairuz Asna ${ }^{1}$

${ }^{1}$ Program Studi S1 Gizi, STIKES Mitra Keluarga, Bekasi, Indonesia

E-mail: .anca.gizi@gmail.com

Naskah diterima : 10-05-2018

Naskah diterbitkan:01-06-2018

\begin{abstract}
Background \& Objective: Anemia is a public health nutrition problem that can occur at any age. In 2013 the proportion of anemia in Indonesia is 21.7 percent. Anemia can be caused by many factors one of which is the consumption pattern. Anemia in girl adolescents and women of reproductive age can cause problem in the first 1000 days of life. This study aims to determine the risk of eating disorders and anemia in nutrition students. Materials and Methods: This study is a cross sectional study with sample 46 girl students and 19 yearsl old. Data collection of risk of eating disorders using questionnaires Eating Attitudes Test (EAT-26)and anemia data obtained from secondary data results of a new student medical check up. Data analyzed by using SPSS, bivariate analysis using chi square test. Results: The results showed 21.7 percent anemia and 26.1 percent risk of eating disorders. 20 percent of students with anemia have an eating disorder risk. The results of statistical tests showed no significant relationship between the risk of eating disorders with anemia. Conclusion: The conclusion of the study is the risk of eating disorders can occur in the student nutrition that may be possible cause of anemia.
\end{abstract}

Keywords: eating disorder, anemia, nutrition student, girl adolescent

\section{ABSTRAK}

Pendahuluan \& Tujuan: Anemia merupakan masalah gizi kesehatan masyarakat yang dapat terjadi pada seluruh usia. Pada tahun 2013 proporsi anemia di Indonesia adalah 21,7 persen. Anemia dapat disebabkan oleh banyak faktor salah satunya adalah pola konsumsi. Anemia pada remaja putri dan wanita usia subur dapat menyebabkan gangguan pada 1000 hari pertama kehidupan. Penelitian ini bertujuan untuk mengetahui risiko gangguan makan dan anemia pada mahasiswa gizi. Bahan dan Metode: Penelitian ini adalah studi cross sectional dengan sampel 46 mahasiswa gizi jenis kelamin perempuan berusia 19 tahun. Pengumpulan data risiko gangguan makan menggunakan kuesioner Eating Attitudes Test (EAT-26) data anemia diperoleh dari data sekunder hasil pemeriksaan kesehatan mahasiswa baru. Data dianalisi dengan menggunakan SPSS, dilakukan analisis bivariat dengan uji chi square. Hasil: Hasil penelitian terdapat 21,7 persen anemia dan 26,1 persen berisiko gangguan makan. 20 persen mahasiswa yang anemia memiliki risiko gangguan makan. Hasil uji statistik memperlihatkan tidak terdapat hubungan yang bermakna antara risiko gangguan makan dengan anemia. Kesimpulan: Kesimpulan penelitian adalah risiko gangguan makan dapat terjadi pada mahasiswa gizi yang memungkinkan dapat menjadi penyebab anemia.

Kata Kunci: gangguan makan, anemia, mahasiswa gizi, remaja putri 


\section{A. Pendahuluan}

Penyelesaian masalah gizi pada 1000 Hari Pertama Kehidupan dapat membantu mengatasi masalah stunting. Kejadian stunting juga dikaitkan dengan masa wanita usia subur. Pencegahan kejadian masalah gizi pada ibu hamil, dapat dimulai dari remaja putri atau wanita usia subur. (Meier, Nickerson, Olson, Berg, \& Meyer, 2003). Anemia merupakan salah satu masalah yang rawan terjadi pada perempuan terutama remaja putri dan wanita usia subur. Proporsi anemia di Indonesia tahun 2013 adalah 21,7\% dan pada perempuan 23,9\% (Kemenkes RI, 2013).

Anemia merupakan salah satu penyakit yang dapat mempengaruhi status kesehatan dan dan kesejahteraan seorang wanita serta meningkatkan risiko ibu hamil terhadap kelahirannya. Saat ini anemia terjadi hampir diseluruh kalangan mulai dari anak-anak sampai dengan orang dewasa, bahkan usia lanjutpun juga rentan atau rawan terhadap kejadian anemia. Salah satu kelompok yang rawan terhadap anemia adalah remaja, khususnya remaja putri. Secara global data menunjukkan bahwa $29 \%$ wanita subur mengalami anemia sedangkan wanita usia 1549 tahun (produktif) mencapai 38\%. WHO menargetkan pada tahun 2025 penurunan $50 \%$ kejadian anemia pada wanita usia produktif (WHO, 2014).

Di Indonesia anemia sebesar 21,7\%. Untuk perempuan sebesar $23,9 \%$ dan untuk usia 15-24 tahun terdapat sebesar 18,4\% yang menderita anemia (Kemenkes RI, 2013). Penelitian dari negara lain juga menunjukkan $21,1 \%$ anemia terjadi pada wanita usia $>15$ tahun di daerah Rural Amazonians, Brasil (Ferreira et al., 2007). Sedangkan hal yang sedikit berbeda dimana kejadian anemia lebih sedikit pada remaja putri di Korea yaitu 4.2\% (Kim et al., 2014). Di Indonesia sendiri data untuk anemia pada remaja putri masih sedikit, secara nasional belum dilakukan analisis lebih lanjut. Namun di beberapa daerah seperti Kota Makassar hasil penelitian menunjukkan $34.36 \%$ remaja putri mengalami anemia, Kabupaten Kudus sebesar 36,8\%. (Farida, Widajanti, \& Pradigdo, 2013; Husnah, Indriasari, \& Jafar, 2014). Di Kota Bekasi sendiri pada tahun 2008 ditemukan 38,3\% anemia pada remaja putri (Briawan, Arumsari, \& Pusporini, 2011).

Banyak faktor yang dapat mempengaruhi kejadian anemia. Anemia terjadi karena kekurangan zat gizi yang diperlukan untuk sintesis eritrosit, terutama besi, vitamin B12, asam folat serta seng. Selebihnya merupakan akibat dari berbagai kondisi seperti pendarahan, kelainan genetik penyakit kronik atau keracunan (Mahan \& Escott-Stump, 2000). Anemia sebagai akibat kekurangan zat gizi disebut anemia gizi, yang sebagian besar disebabkan kekurangan besi yang lazim disebut anemia gizi besi, masalah ini terutama menjangkiti para wanita dalam usia reproduktif dan anak-anak kawasan tropis dan subtropis (Hoffbrand, Petit, \& Moss, 2005; Vijayaraghavan, 2004).

Kekurangan zat besi disebabkan oleh kurangnya asupan atau karena ada zat yang menghambat penyerapan zat besi contoh seng jika berlebihan akan menggangu penyerapan besi (Gibney, 2013). Selain hal tersebut Briawan dkk menyebutkan bahwa faktor risiko anemia pada remaja putri adalah usia pertama menstruasi dan status antropometri (Briawan et al., 2011).

Rendahnya asupan zat besi sering terjadi pada orang-orang yang mengkonsumsi bahan makananan yang kurang beragam dengan menu makanan yang terdiri dari nasi, kacangkacangan dan sedikit daging, unggas, ikan yang merupakan sumber zat besi (Stoltzfus et al., 1999). Faktor determinan lainnya adalah dipengaruhi oleh tingkat konsumsi energi, zat besi dan vitamin A sementara penelitian di Kota Makassar, Sulawesi Selatan, memperlihatkan tidak ada hubungan yang signifikan antara asupan makan dan kadar hemoglobin $(\mathrm{Hb})$ pada remaja putri (Farida et al., 2013; Husnah et al., 2014). Sebaliknya penelitian di Kota bekasi menyatakan terdapat hubungan konsumsi beberapa makanan dengan anemia, seperti konsumsi sayuran, buah-buahan serta lauk hewani (Briawan et al., 2011).

Penelitian di Brasil menyarankan penelitian lebih lanjut mengenai faktor yang menyebabkan rendahnya kadar $\mathrm{Hb}$ pada remaja putri karena hasil analisis tidak memperlihatkan adanya hubugan yang bermakna antara asupan dan anemia pada remaja putri (Bagni, Yokoo, \& Veiga, 2013). Rendahnya asupan sangat dipengaruhi oleh pola makan. Masa remaja, khususnya remaja putri sangat peduli dengan pola makannya agar menjaga tubuhnya tetap ideal dan kemungkinan dapat terjadi kekurangan gizi. Banyaknya metode diet yang tidak sesuai dengan prinsip-prinsip gizi dapat menyebabkan asupan yang terganggu.

Anemia defesiensi besi pada masa remaja tidak hanya menurunkan produktifitas tetapi pada gilirannya akan menggiring remaja putri pada kondisi anemia di masa kehamilan nanti. Ibu hamil yang menderita anemia akan mempertinggi resiko untuk mengalami 
keguguran, perdarahan waktu melahirkan, dan melahirkan bayi dengan berat lahir rendah. Akibat jangka panjang dari anemia pada remaja putri adalah apabila remaja putri hamil, maka ia tidak akan mampu memenuhi kebutuhan zat-zat gizi bagi dirinya dan juga janin dalam kandungannya. Oleh karena itu keguguran, kematian bayi dalam kandungan, berat badan lahir rendah atau kelahiran prematur rawan terjadi pada ibu hamil yang menderita anemia (Gibney, 2013; Kätelhut, Schultink, Angeles, Gross, \& Pietrzik, 1996).

Anemia dapat disebabkan oleh kurangnya asupan atau konsumsi zat gizi. Beberapa penelitian telah membuktikan bahwa pola makan yang tidak benar dapat menyebabkan kadar hemoglobin rendah, termasuk yang asupan zat besi rendah dan diet vegetarian (Creed-Kanashiro et al., 2000; Iş1k Balc1, Karabulut, Gürses, \& Ethem Çövüt, 2012; Kaur, Deshmukh, \& Garg, 2006). Pola makan yang tidak benar dapat terjadi karena remaja mengalama risiko gangguan makan. Di Taiwan, 43,2\% mahasiswa putri teridentifikasi mengalami risiko gangguan makan. Lebih lanjut risiko gangguan makan ini berkaitan dengan diet yang tidak sehat. Diet ini cepat tersebar dikalangan mahasiswa putri yang ingin menurunkan berat badan. Diet tidak sehat ini adalah pola makan yang tidak sesuai dengan gizi seimbang. Dari data sebanyak $67,6 \%$ mengalami kehilangan berat badan dan dapat menuju status gizi kurang/kurus akibat dari diet yang tidak sehat (Yeh et al., 2009).

Risiko gangguan makan diketahui dapat menyebabkan masalah gizi yaitu kejadian anoreksia dan bulimia serta binge eating. Gangguan makan ini berakibat pada kekurangan dan kelebihan gizi (Lask \& Bryant-Waugh, 2013). Masalah lain yang dapat timbul adalah kekurangan zat gizi mikro. Akibat kurangnya asupan, lebih dari $50 \%$ remaja putri memiliki asupan kalsium, magnesium, besi, vitamin $\mathrm{D}$ dan $\mathrm{E}$ yan tidak cukup (Mensink et al., 2013; Moore, Singer, Qureshi, Bradlee, \& Daniels, 2012). Dengan melihat tingginya kejadian anemia di berbagai daerah dan melihat akibat dari anemia pada remaja putri yang berdampak jangka pendek dan panjang serta pola diet yang yang salah pada remaja putri membuat peneliti ingin melakukan peneltian mengenai risiko gangguan makan dan anemia pada mahasiswa putri.

\section{B. BAHAN DAN METODE}

\section{Desain penelitian}

Penelitian ini adalah penelitian observasional dengan rancangan cross- sectional. Penelitian di lakukan di Sekolah Tinggi Ilmu Kesehatan Mitra Keluarga, Bekasi, Jawa Barat. Penelitian dilaksanakana pada bulan Januari - Februari 2018.

\section{Populasi dan Sampel}

Populasi adalah seluruh mahasiswa Program Studi S1 Gizi STIKes Mitra Keluarga. Sampel penelitian ditentukan dengan total sampling. Sampel yang diperoleh adalah 46 orang dengan kriteria memiliki hasil pemeriksaan kesehatan dan berusia 19 tahun.

\section{Pengumpulan Data}

Data dikumpulkan dengan menggunakan kuesioner. Risiko gangguan makan diperoleh dari pertanyaan kuesioner EAT 26. Data Anemia diperoleh dari data sekunder yaitu hasil pemeriksaan kesehatan mahasiswa.

\section{Analisis Data}

Data dianalisis menggunakan bantuan SPSS. Jenis analisiswa yang digunakan adalah analisis bivariat untuk melihat hubungan risiko gangguan makan dengan anemia dengan nilai $\mathrm{p}<0,05$

\section{HASIL}

Sebanyak 46 mahasiswa putri dengan umur 19 tahun telah diambil data dan dianalisis. Dari hasil analisis deskriptif diketahui bahwa rerata tinggi badan responden adalah $156,5 \mathrm{~cm}$ dan berat badan $54,10 \mathrm{~kg}$. Rerata hasil pemeriksaan hb adalah $12,84 \mathrm{~g} / \mathrm{dl}$. Selain itu hasil dari skor eating attitudes test (EAT 26) adalah 9. Hasil lebih lengkap dapat dilihat pada tabel 1 .

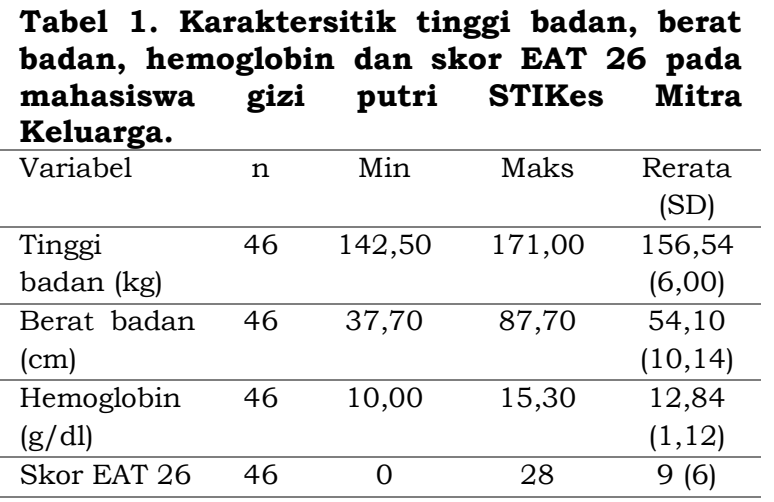

Hasil uji statistik hubungan risiko gangguan makan dengan anemia dapat dilihat pada tabel 2 berikut. Dari tabel 2 diketahui bahwa $20 \%$ responden memiliki risiko gangguan dan anemia. Hasil uji chi square memperlihatkan tidak terdapat hubungan yang bermakna antara risiko gangguan makan dan anemia.

\section{PEMBAHASAN}

Sampel penelitian adalah mahasiswa putri yang berusia 19 tahun. Usia 19 tahun masih merupakan kategori remaja akhir yang telah 
siap untuk memasuki dewasa muda (Ahmad et al., 2011). Pada usia ini penting untuk memperhatikan asupan agar tidak terjadi anemia. Remaja putri termasuk salah satu yang rentan terjadi anemia (WHO, 2014). Berdasarkan hasil penelitian ditemukan 21,7\% mahasiswa putri anemia dengan kadar hemoglobin kurang dari $12 \mathrm{~g} / \mathrm{dL}$. Hasil ini lebih rendah dibanding dengan kejadian anemia pada perempuan di Indonesia (23,9\%). Namun angka ini masih merupakan masalah kesehatan masyarakat (20-39,9\%) dengan kategori sedang (Benoist, McLean, Egli, \& Cogswell, 2008). Rerata hemoglobin sampel adalah $12,84 \mathrm{~g} / \mathrm{dl}$ (tabel 1.) berada sedikit diatas nilai normal $(12 \mathrm{~g} / \mathrm{dL})(3,4,13)$. Untuk mempertahankan kadar hb tetap normal perlu asupan makanan yang cukup.

Tabel 2. Risiko gangguan makan dan anemia pada mahasiswa gizi putri STIKes Mitra Keluarga.

\begin{tabular}{|c|c|c|c|c|}
\hline Variabel & $\begin{array}{c}\text { Anemia } \\
\mathrm{n}(\%)\end{array}$ & $\begin{array}{c}\text { Tidak } \\
\text { Anemia } \\
\text { n (\%) }\end{array}$ & $\begin{array}{c}\text { Total } \\
(\%)\end{array}$ & Nilai $p$ \\
\hline \multicolumn{4}{|c|}{ Risiko Gangguan Makan } & \multirow{4}{*}{0,620} \\
\hline $\begin{array}{l}\text { Tidak } \\
\text { Risiko }\end{array}$ & $8(80)$ & $\begin{array}{c}26 \\
(72,2)\end{array}$ & $\begin{array}{c}34 \\
(73,9)\end{array}$ & \\
\hline Risiko & $2(20)$ & $\begin{array}{c}10 \\
(27,8)\end{array}$ & $\begin{array}{c}12 \\
(26,1)\end{array}$ & \\
\hline Total & $10(21,7)$ & $36(78,3$ & $\begin{array}{c}46 \\
(100)\end{array}$ & \\
\hline
\end{tabular}

Beberapa penelitian menunjukkan bahwa anemia pada remaja putri disebabkan oleh multi faktor, salah satunya adalah asupan zat gizi yang kurang, baik zat gizi makro ataupun zat gizi mikro (Briawan et al., 2011; CreedKanashiro et al., 2000). Penelitian ini tidak melihat data asupan, namun melihat risiko gangguan makan yang terjadi pada mahasiswa putri atau remaja putri. Risiko gangguan makan ini akan berdampak pada pola makan dan asupan. Diketahui bahwa risiko gangguan makan ini berhubungan erat dengan kejadian anoreksia dan bulimia. Seseorang yang menderita anoreksia berhubungan dengan kekurangan protein dan energi yang kemungkinan besar menyebabkan gangguan pada pembentukan sel darah merah (Hadigan et al., 2000; Wysokiński, Sobów, Kłoszewska, \& Kostka, 2015).

Berdasarkan hasil penelitian ditemukan $26,1 \%$ mahasiswa putri yang memiliki risiko gangguan makan (skor >20). Hasil ini diperoleh berdasarkan pertanyaan dari eating attitude test (EAT 26). Hasil ini lebih tinggi dibanding penelitian yang dilakukan oleh Kurniawan dkk, dimana mahasiswa putri dengan gangguan makan hanya 7,8\% (Kurniawan, Briawan, \& Caraka, 2015). Hasil yang sama juga terjadi pada penelitian di
Yogyakarta, hanya 12,2\% remaja putri yang mengalami risiko gangguan makan (Sulistyan, Huriyati, \& Hastuti, 2017). Risiko gangguan makan kemungkinan besar terjadi pada remaja yang memiliki persepsi tubuh negative (Pike \& Dunne, 2015).

Berdasarkan uji chi square tidak terdapat hubungan yang bermakna antara risiko gangguan makan dengan kejadian anemai pada mahasiswa putri. Walaupun demikian dari hasil penelitian diketahui bahwa dua dari sepuluh mahasiswa putri dengan risiko gangguan makan mengalami anemia (hb <12 g/dl). Penelitian terkait anemia dan risiko gangguan makan sangat terbatas bahkan belum ada data terbaru. Satu-satunya yang membuat ini masuk akal adalah dengan menyadari bahwa risiko gangguan makan ini berhubungan erat dengan gangguan makan seperti anoreksi dan bulimia. Beberapa penelitian menyebutkan bahwa anoreksia dan bulimia nevrosa dapat menjadi faktor risiko anemia (Beals \& Manore, 1994; Iş1k Balcı et al., 2012; Mamou, Sider, Bouscary, Moro, \& Blanchet-collet, n.d.). Hal lain yang dapat terjadi dari risiko gangguan makan pada remaja adalah ketidakcukupan asupan zat gizi, seperti protein dan zat besi yang dapat menyebabkan anemia (Lask \& Bryant-Waugh, 2013; Moore et al., 2012).

\section{E. KESIMPULAN}

Anemia merupakan masalah kesehatan masyarakat dengan multi faktor. Risiko gangguan makan pada remaja putri kemungkinan dapat menyebabkan anemia. Walaupun demikian tidak terdapat hubungan yang bermakna antara risiko gangguan makan dan anemia. Penelitian lebih lanjut perlu mengkaji jenis risiko gangguan makan, dengan demikian dapat menentukan risiko mana yang memiliki pengaruh besar terhadap kejadian anemia.

\section{F. DAFTAR PUSTAKA}

Ahmad, O. B., Boschi-Pinto, C., Lopez, A. D., Murray, C., Lozano, R., \& Inoue, M. (2011). Age standardization of rates: a new WHO standard. World Health Organization.

Bagni, U. V., Yokoo, E. M., \& Veiga, G. V. da. (2013). Association between Nutrient Intake and Anemia in Brazilian Adolescents. Annals of Nutrition and Metabolism, 63(4), 323-330. https://doi.org/10.1159/000357955 
Beals, K. A., \& Manore, M. M. (1994). The prevalence and consequences of subclinical eating disorders in female athletes. International Journal of Sport Nutrition, 4(2), 175-195.

Benoist, B. de, McLean, E., Egli, I., \& Cogswell, M. (2008). Worldwide prevalence of anaemia 1993-2005. WHO Global Database on Anaemia. World Health Organization.

Briawan, D., Arumsari, E., \& Pusporini, P. (2011). Faktor Risiko Anemia Pada Siswi Peserta Program Suplementasi. Jurnal Gizi Dan Pangan, 6(1), 74-83. https://doi.org/ 10.25182/jgp.2011.6.1.74 $-83$

Creed-Kanashiro, H. M., Uribe, T. G., Bartolini, R. M., Fukumoto, M. N., López, T. T., Zavaleta, N. M., \& Bentley, M. E. (2000). Improving dietary intake to prevent anemia in adolescent girls through community kitchens in a periurban population of Lima, Peru. The Journal of Nutrition, 130(2S Suppl), 459S-461S. https://doi.org/10.1093/jn/130.2.459S

Farida, I., Widajanti, L., \& Pradigdo, S. F. (2013). Determinan kejadian anemia pada remaja putri di Kecamatan Gebog Kabupaten Kudus tahun 2006. Jurnal Gizi Indonesia (The Indonesian Journal of Nutrition), 2(1). https://doi.org/10.14710/jgi.2.1.

Ferreira, M. U., da Silva-Nunes, M., Bertolino, C. N., Malafronte, R. S., Muniz, P. T., \& Cardoso, M. A. (2007). Anemia and Iron Deficiency in School Children, Adolescents, and Adults: A CommunityBased Study in Rural Amazonia. American Journal of Public Health, 97(2), 237-239. https://doi.org/10.2105/AJPH.2005.0781 21

Gibney, M. J. (2013). Gizi Kesehatan Masyarakat. Jakarta: EGC.

Hadigan, C. M., Anderson, E. J., Miller, K. K., Hubbard, J. L., Herzog, D. B., Klibanski, A., \& Grinspoon, S. K. (2000). Assessment of macronutrient and micronutrient intake in women with anorexia nervosa. The International Journal of Eating Disorders, 28(3), 284-292.

Hoffbrand, A. ., Petit, J. ., \& Moss, P. A. . (2005). Kapita Selekta Hematologi (Edisi ke 6). Jakarta: EGC.

Husnah, N., Indriasari, R., \& Jafar, N. (2014, August 19). Hubungan Makanan Sumber Heme Dan Non Heme Terhadap Kadar Hb Remaja Putri SMA 10 Makassar Tahun 2014. Universitas Hasanuddin, Makassar. Retrieved from http://repository.unhas.ac.id/handle/123
456789/10595

Iş1k Balc1, Y., Karabulut, A., Gürses, D., \& Ethem Çövüt, İ. (2012). Prevalence and Risk Factors of Anemia among Adolescents in Denizli, Turkey. Iranian Journal of Pediatrics, 22(1), 77-81.

Kätelhut, A., Schultink, W., Angeles, I., Gross, R., \& Pietrzik, K. (1996). The effects of weekly iron supplementation with folic acid, vitamin $\mathrm{A}$, vitamin $\mathrm{C}$ on iron status of Indonesian adolescents. Asia Pacific Journal of Clinical Nutrition, 5(3), 181-185.

Kaur, S., Deshmukh, P. R., \& Garg, B. . (2006). Epidemiological correlates of nutritional anemia in adolescent girls of rural Wardha. Indian Journal of Community Medicine, 31(4), 255-258.

Kemenkes RI. (2013). Riset Kesehatah Dasar Tahun 2013. Badan Penelitian dan Pengembangan Kesehatan Departemen Kesehatan Republik Indonesia.

Kim, J. Y., Shin, S., Han, K., Lee, K.-C., Kim, J.-H., Choi, Y. S., ... Ko, B.-J. (2014). Relationship between socioeconomic status and anemia prevalence in adolescent girls based on the fourth and fifth Korea National Health and Nutrition Examination Surveys. European Journal of Clinical Nutrition, 68(2), 253-258. https://doi.org/10.1038/ejcn.2013.241

Kurniawan, M. Y., Briawan, D., \& Caraka, R. E. (2015). Persepsi tubuh dan gangguan makan pada remaja. Jurnal Gizi Klinik Indonesia, 11(3), 105-114. https://doi.org/10.22146/ijcn. 19287

Lask, B., \& Bryant-Waugh, R. (2013). Eating Disorders in Childhood and Adolescence (4th Edition). Oxford: Routledge.

Mahan, L. K., \& Escott-Stump, S. (2000). Krause's food, nutrition, and diet therapy (10th ed). Philadelphia, Pa.: W.B. Saunders. Retrieved from https://trove.nla.gov.au/version/4457628 7

Mamou, G., Sider, A., Bouscary, D., Moro, M. R., \& Blanchet-collet, C. (2016). Anemia in Anorexia Nervosa: the Best Way to Deal with it- An Overview of Literature. J Hum Nutr Food Sci, 4(1), 1081.

Meier, P. R., Nickerson, H. J., Olson, K. A., Berg, R. L., \& Meyer, J. A. (2003). Prevention of Iron Deficiency Anemia in Adolescent and Adult Pregnancies. Clinical Medicine and Research, 1(1), 29-36.

Mensink, G. B. M., Fletcher, R., Gurinovic, M., Huybrechts, I., Lafay, L., Serra-Majem, L., ... Stephen, A. M. (2013). Mapping low intake of micronutrients across Europe. The British Journal of Nutrition, 110(4), 755-773. 
https://doi.org/10.1017/S000711451200 $565 \mathrm{X}$

Moore, L. L., Singer, M. R., Qureshi, M. M., Bradlee, M. L., \& Daniels, S. R. (2012). Food Group Intake and Micronutrient Adequacy in Adolescent Girls. Nutrients, 4(11), 1692-1708. https://doi.org/10.3390/nu4111692

Pike, K. M., \& Dunne, P. E. (2015). The rise of eating disorders in Asia: a review. Journal of Eating Disorders, 3, 33. https://doi.org/10.1186/s40337-0150070-2

Stoltzfus, R. J., Edward-Raj, A., Dreyfuss, M. L., Albonico, M., Montresor, A., Dhoj Thapa, M., ... Tielsch, J. (1999). Clinical pallor is useful to detect severe anemia in populations where anemia is prevalent and severe. The Journal of Nutrition, 129(9), 1675-1681. https://doi.org/10.1093/jn/129.9.1675

Sulistyan, A., Huriyati, E., \& Hastuti, J. (2017). Distorsi citra tubuh, perilaku makan, dan fad diets pada remaja putri di Yogyakarta. Jurnal Gizi Klinik Indonesia, 12(3),

https://doi.org/10.22146/ijcn.22644
Vijayaraghavan, K. (2004). Anemia Karena Defisiensi Zat Besi. Gizi Kesehatan Masyarakat. Jakarta: EGC.

WHO. (2014). Global Nutrition Targets 2025: Anaemia policy brief. World Health Organization. Retrieved from http://www.who.int/nutrition/publication s/globaltargets2025_policybrief_anaemia/ en/

Wysokiński, A., Sobów, T., Kłoszewska, I., \& Kostka, T. (2015). Mechanisms of the anorexia of aging-a review. Age (Dordrecht, Netherlands), $\quad 37(4), \quad 9821$. https://doi.org/10.1007/s11357-0159821-x

Yeh, H.-W., Tzeng, N.-S., Chu, H., Chou, Y.-H., Lu, R.-B., O’Brien, A. P., ... Chou, K.-R. (2009). The risk of eating disorders among female undergraduates in Taiwan. Archives of Psychiatric Nursing, 23(6), 430440.

https://doi.org/10.1016/j.apnu.2008.12. 001 